\title{
Evaluation of the Number of Gastric Mucoid Epitheliocytes and Parietal Cells in Relation to the Amount of Helicobacteria in the Fundic Gland Region of Domestic Dogs (Canis Familiaris)
}

\author{
Dace Bērziṇa*, Edīte Birğele \\ Preclinical Institute, Faculty of Veterinary Medicine, LLU, K. Helmaņa iela 8, Jelgava LV-3004, Latvia
}

\begin{abstract}
This study was done to evaluate the number of gastric mucoid epitheliocytes and parietal cells in relation to the amount of helicobacteria in the fundic gland region of 30 domestic dogs (Canis familiaris). Gastric mucosa samples were taken from the fundic gland region in eight strictly determined places to detect helicobacteria in 10 microscopic visual fields by histological examination, to find out the quantity of helicobacteria at the superficial epithelium, in gastric pits, and in fundic glands by classifying it as absent, mild, moderate, and severe, as well as to evaluate the number of mucoid epitheliocytes of the gastric superficial-pit epithelium and of the parietal cells of fundic glands. Out of all examined 2400 microscopic visual fields, mild and moderate amounts of helicobacteria localizing mainly at the superficial epithelium and in gastric pits were detected in $69.0-77.5 \%$ of cases, and only in around $20 \%$ of cases they were found in different amounts deeper into the fundic glands. The number of mucoid epitheliocytes (199 \pm 20 cells in one visual field) was only slightly larger in places with a severe amount of helicobacteria compared to places with no helicobacteria (195 \pm 16 mucoid epitheliocytes in one visual field). Also the number of parietal cells in the fundic glands did not differ markedly among the places with different amounts of helicobacteria; however, in places with a severe amount of helicobacteria, parietal cell count tended to decrease to $76 \pm 8$ cells in one visual field, but in places free from helicobacteria there were $83 \pm 9$ parietal cells in one visual field.
\end{abstract}

Key words: Dogs, helicobacteria, epithelium, parietal cells.

\section{Introduction}

Gastric helicobacteria are common in domestic dogs, but their pathogenic effect is still quite contradictious. Some authors consider that such pathological changes of the gastric mucosa as gastritis, erosions or ulcers are not related to the presence of helicobacteria in the mucosa of the stomach (Happonen et al., 1998; Hwang, Han, \& Youn, 2002); however, others have observed a marked infiltration of neutrophils, lymphocytes and plasmocytes in the gastric mucosa, as well as changes in the amount and function of parietal and other mucosal cells in the gastric mucosa with helicobacteria (Eaton et al., 1996; Flahou et al., 2010; Simpson et al., 2000; Smolka \& Backert, 2012; Yamasaki, Suematsu, \& Takahasi, 1998).

Animal gastric helicobacteria are most identified in the mucoid secretion at the mucosal superficial epithelium, in the gastric pits, in the lumen of the glands, and in the parietal cell canaliculi of the fundic gland region (Geyer, Colbatzsky, Lechner, \& Hermanns, 1993; Hwang, Han, \& Youn, 2002; Lanzoni et al., 2011; Yamasaki, Suematsu, \& Takahasi, 1998). It would be useful to investigate the role of the mucoid secretion and gastric acid as the defense mechanism during helicobacter infection in the gastric mucosa. Almost all helicobacteria produce the enzyme urease that breaks down the urea releasing ammonia which decreases the acid level at the superficial epithelial cells of gastric mucosa, thus providing the optimum environment for them to survive and multiply. A low acid level (higher $\mathrm{pH}$ ) at the gastric mucosa may also arise due to parietal cell damage, mucosal gland occlusions with desquamated epitheliocytes, mucoid secretion, and inflammatory cells which proliferate in cases of helicobacter infection (Eaton et al., 1996; Wang et al., 2008).

Unlike the widely studied pathogenesis of the Helicobacter pylori-induced injury in the human gastric mucosa, the effect on gastric mucosa changes

\footnotetext{
* Corresponding author's email: 
caused by most common animal helicobacter species is uncertain. Some studies suggest that gastric helicobacteria of Mongolian gerbils cause apoptosis and loss of parietal cells as, well as their replacement of other glandular epithelial cells (Happonen et al., 1998; Kaori, Shinichi, \& Masahiko, 2004). Other studies suggest that in cheetahs, those helicobacteria which localise in the parietal cell canaliculi cause decrease in the amount of parietal cells, chief cells and mucoid cells, and often are related to the development of gastric ulcer and infiltration of the neutrophil leucocytes, lymphocytes and plasmocytes in the gastric mucosa (Kanou et al., 2005; Terio, Munson, \& Moore, 2011).

The aim of this study was to evaluate the number of gastric mucoid epitheliocytes and parietal cells in relation to the amount of helicobacteria in the fundic gland region of domestic dogs (Canis familiaris).

The main tasks of the research were:

1) to detect helicobacteria in the fundic gland region of gastric mucosa by histological examination;

2) to find out the amount of helicobacteria at the gastric superficial epithelium, in gastric pits, and in fundic glands of the gastric mucosa.

3) to evaluate the number of mucoid epitheliocytes of the gastric superficial-pit epithelium and parietal cells of the fundic glands in relation to the amount of the helicobacteria in the gastric mucosa of the fundic gland region.

\section{Materials and Methods}

The research material was obtained at the Faculty of Veterinary Medicine of the Latvia University of Agriculture. Gastric mucosa samples were collected from 30 domestic dogs of different age and sex immediately after euthanasia (with permission of the owner).

Gastric mucosa samples were taken from the fundic gland region in eight strictly determined places; in total - 240 samples.

The samples were collected for histological examination and primed for analysis using the classical preparation methods (Carson, 1997) by applying a Tissue-Tek II (NL) autoprocessor and sectioning the paraffin blocks into $4 \mu \mathrm{m}$ slides by a SLEE Mainz Cut microtome. The Diff-Quik staining method was used to detect helicobacteria, but the Hematoxylin and eosine (H\&E) staining method was used to evaluate parietal cells of the gastric mucosa. Histological samples were viewed using a Leica DM5000B optical microscope at 400× magnification.

In each histological sample, 10 microscopic visual fields were evaluated for helicobacteria amount at the superficial epithelium, in gastric pits, and deeper into the mucosa at glandulocytes (Happonen et al., 1996; Hermanns, Kregel, Breuer, \& Lechner, 1995; Vorobjova, Hurlimann, Zimmermann, Uibo, \& Halter, 2005). In each mucosa histological sample of the fundic gland region, the amount of helicobacteria was arranged into four groups (Happonen et al., 1998): no helicobacteria in one visual field - absent; $1-10$ helicobacteria in one visual field - mild; 10-50 helicobacteria in one visual field - moderate; and more than 50 helicobacteria in one microscopic visual field - severe.

The number of mucoid epitheliocytes and parietal cells was evaluated in one microscopic visual field that is $215000 \mu \mathrm{m}^{2}\left(0.215 \mathrm{~mm}^{2}\right)$ large. Overall, in one sample there were up to 10 microscopic visual fields of the upper parts of the mucosa - at the superficial-pit epithelium and in the deeper glandular epithelium. In total, 2400 microscopic visual fields of the 240 collected samples from the fundic gland region were analyzed.

The amount of mucoid epitheliocytes was analyzed by calculating the average number \pm standard deviation of these cells at the superficial epithelium and in gastric pits. Parietal cell number was determined by calculating the average number \pm standard deviation of these cells in the upper parts of the fundic region - up to $450 \mu \mathrm{m}$ deep in the mucosa, and deeper into the glandular part - up to $850 \mu \mathrm{m}$ (Fukui et al., 2003; Kakehasi, Mendes, Coelho, Castro, \& Barbosa, 2007; Shao et al., 2000). The depth of gastric mucosa, as well as the size of visual fields was determined using the measuring-analytic program "Image-Pro Plus".

The mathematical analysis of data and the formation of diagrams were produced using MS Excel and SPSS 11.5 program (Arhipova \& Bāliņa, 2003). The Mann-Whitney U-test was used for the analysis of the location and amount of helicobacteria in the gastric mucosa. The mucoid epitheliocyte and parietal cell number related to the amount of mucosal helicobacteria was analyzed using Student's t-test for the comparison of two sample groups (Paura \& Arhipova, 2002). 


\section{Results and Discussion}

In the present research, firstly, we detected the amount of helicobacteria at the superficial epithelium, in gastric pits, and deeper into the mucosa in the gastric glands of the gastric fundic gland region. Depending on the amount of helicobacteria in one microscopic visual field, four groups were formed: absent, mild, moderate, and severe.

The presence and amount of helicobacteria were evaluated up to $170 \mu \mathrm{m}$ deep in the gastric pits, and up to $350 \mu \mathrm{m}$ deep into the fundic glandular epithelium. Table 1 shows the percentage of all examined 2400 microscopic views of the collected mucosa samples in relation to the amount of helicobacteria in different parts of the mucosa collected from the fundic gland region.

The location of helicobacteria was prevalently concentrated at the superficial epithelium and in gastric pits $(p<0.01)$. In the fundic region, a moderate amount (10-50 bacteria in one visual field) of helicobacteria was detected in $69.0 \%$ of cases at the superficial epithelium, and in $77.5 \%$ of cases in gastric pits. A mild amount of helicobacteria (1-10 bacteria in one visual field) was found in $19.0 \%$ of cases at the superficial epithelium, and in $10.0 \%$ of cases in gastric pits. A severe amount of helicobacteria (more than 50 bacteria in one visual field) was only in $5.0 \%$ of cases at the superficial epithelium, and in $7.5 \%$ of cases in gastric pits.

Deeper into the fundic glands, helicobacteria were substantially less than at the superficial epithelium and in gastric pits $(p<0.01)$. In $80.0 \%$ of cases, helicobacteria were absent at the fundic glandular epithelium, whereas up to $350 \mu \mathrm{m}$ deep into the fundic glandular epithelium, the amount of helicobacteria was mild in $10.0 \%$ of cases, moderate in $6.0 \%$ of cases, and severe in $4.0 \%$ of cases.

Out of all examined samples from the fundic gland region, in $69.0-77.5 \%$ of cases, helicobacteria were in moderate amounts (10-50 helicobacteria in one visual field) and localized mainly at the superficial epithelium and in gastric pits, and only in around $20 \%$ of cases they were found in different amounts deeper into the fundic glands. It is known that pathogenic helicobacteria species can infect even the parietal cell canaliculi causing cell damage and inflammation of the gastric mucosa (Diker, Haziroglu, Akan, Celik, \& Kabacki, 2002; Geyer, Colbatzsky, Lechner, \& Hermann, 1993; Happonen et al., 1998; Hwang, Han, \& Youn, 2002; Joo et al., 2007; Robic et al., 2007; Yamasaki, Suematsu, \& Takahasi, 1998).

The next task was to analyze the number of gastric superficial-pit mucoid epitheliocytes and fundic gland parietal cells in relation to the amount of helicobacteria located in the gastric mucosa of the fundic gland region. The number of the mucoid epitheliocytes at the superficial and gastric pit epithelium is shown in Figure 1.

It is seen that the number of mucoid epitheliocytes at the gastric superficial-pit epithelium of the fundic gland region is slightly larger in places with different amounts of helicobacteria compared to the places where bacteria were not detected $(p>0.05)$. The average number of the mucoid epitheliocytes of the gastric superficial-pit epithelium in one microscopic visual field without helicobacteria was $195 \pm 16$, but in places with mild, moderate, and severe amounts of helicobacteria - $198 \pm 19,197 \pm 21$, and $199 \pm 20$, respectively (Fig. 1).

The number of fundic gland parietal cells was evaluated in the upper parts of fundic glands up to $450 \mu \mathrm{m}$ deep, and in deeper parts - up to $850 \mu \mathrm{m}$ as far as lamina muscularis mucosae. In the deeper parts of fundic glands, no helicobacteria were detected, and the average number of parietal cells was $86 \pm 7$ in one microscopic visual field. In the upper parts of fundic glands, there were places with no helicobacteria, and places with mild,

Table 1

The amount of helicobacteria in the gastric mucosa of the fundic gland region

\begin{tabular}{|c|c|c|c|c|}
\hline \multirow{2}{*}{$\begin{array}{l}\text { Location of helicobacteria in } \\
\text { the gastric mucosa }\end{array}$} & \multicolumn{4}{|c|}{$\begin{array}{l}\text { Percentage of } 2400 \text { microscopic visual fields } \\
\text { with different amounts of helicobacteria }\end{array}$} \\
\hline & absent & mild & moderate & severe \\
\hline Superficial epithelium & $7.0 \%$ & $19.0 \%$ & $69.0 \%$ & $5.0 \%$ \\
\hline Gastric pits & $5.0 \%$ & $10.0 \%$ & $77.5 \%$ & $7.5 \%$ \\
\hline Fundic glandular epithelium & $80.0 \%$ & $10.0 \%$ & $6.0 \%$ & $4.0 \%$ \\
\hline
\end{tabular}




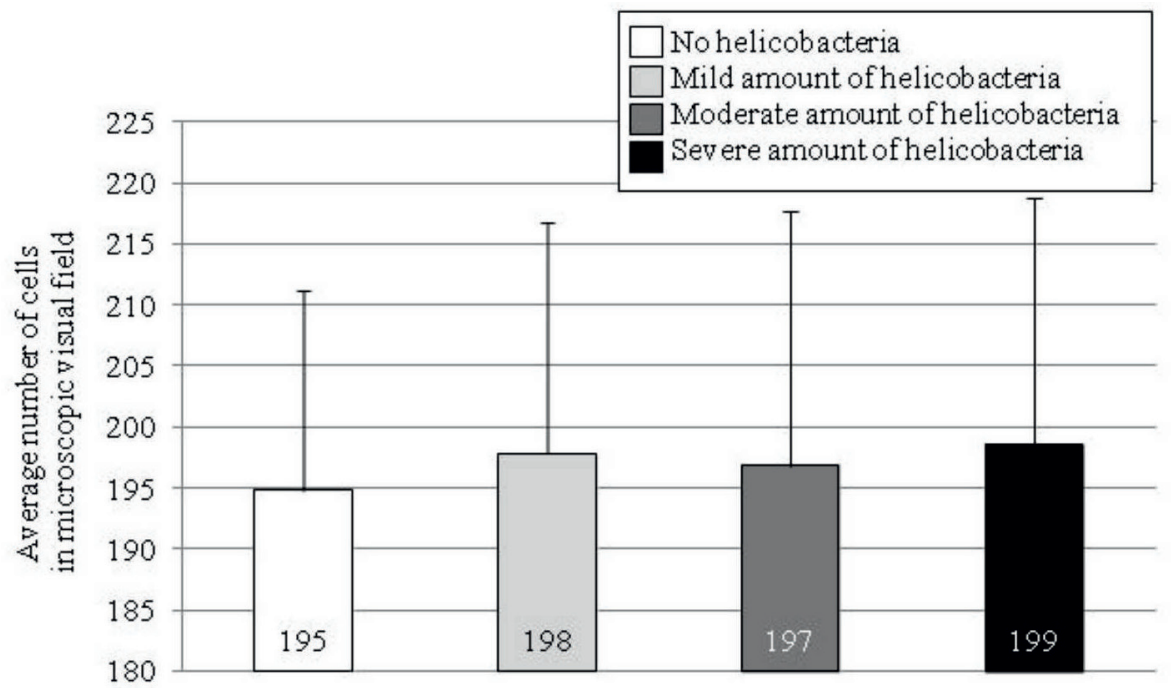

Fig. 1. The number of mucoid epitheliocytes in the gastric mucosa of the fundic gland region according to the amount of helicobacteria in one microscopic visual field.

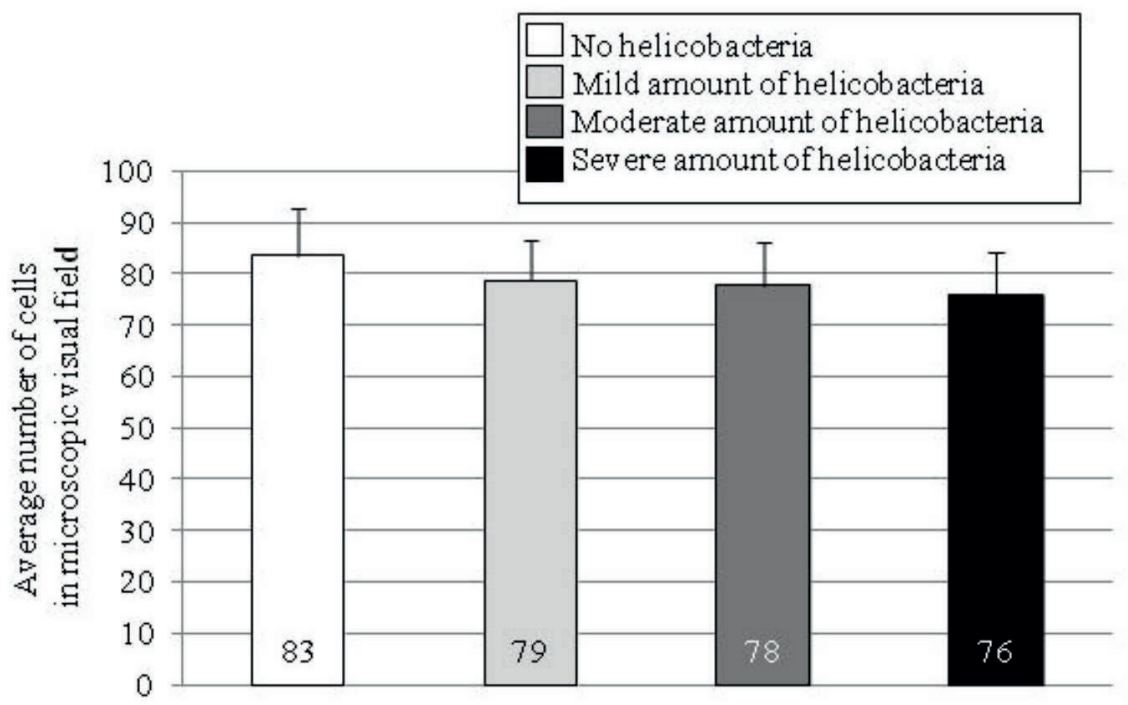

Fig. 2. The number of parietal cells in the gastric mucosa of the fundic gland region according to the amount of helicobacteria in one microscopic visual field.

moderate and severe amounts of helicobacteria. The number of parietal cells in these places is shown in Figure 2.

In the upper parts of the fundic glandular epithelium with no helicobacteria, $83 \pm 9$ parietal cells were detected in one microscopic visual field. In general, this is only slightly more than in places with different amounts of helicobacteria. In places with mild amounts of helicobacteria, there were $79 \pm 8$ parietal cells in one visual field, in places with moderate amounts of helicobacteria -
$78 \pm 8$ parietal cells, and in places with severe amounts of helicobacteria $-76 \pm 8$ parietal cells in one visual field. It can be concluded that no significant differences in the number of parietal cells were observed among the places with different amounts of helicobacteria $(p>0.05)$. However, it has to be taken into consideration that the number of parietal cells in the fundic glands had a little decrease in places where helicobacteria were present. For comparison, the data of the research on the humans infected with pathogenic 
helicobacteria (e.g. Helicobacter pylori) indicate a significant decrease in the number of parietal cells (Haesebrouck et al., 2009; Joo et al., 2007). The results of our research showed that in the fundic gland region of domestic dogs, helicobacteria did not cause a significant decrease in the number of parietal cells and subsequently - in the hypersecretion of hydrochloric acid.

In general, our research suggests that the influence of helicobacteria on the number of mucoid epitheliocytes and parietal cells in the gastric mucosa of the fundic gland region was not considerable. However, there was a clearly seen tendency for mucoid epitheliocytes to proliferate at the gastric superficial-pit epithelium, which means that there was a small formation of a defense reaction in the mucosa of the fundic gland region, as well as a decrease in the number of parietal cells in the fundic glands, which in its turn indicates a soft destructive effect on the fundic glandular epithelium of the gastric mucosa in the domestic dogs.

\section{Conclusions}

1. Helicobacteria in the gastric mucosa of the fundic gland region were present mostly in mild and moderate amounts localizing mainly at the gastric superficial-pit mucoid epithelium.

2. In the mucosa samples with different amounts of helicobacteria from the fundic gland region, the number of mucoid epitheliocytes did not significantly change, but only indicated a small proliferation of the mucoid epitheliocytes in places with larger amounts of helicobacteria.

3. The number of parietal cells in the fundic glands also did not have any marked changes in places with different amounts of helicobacteria; however, in case of a significant increase in the number of helicobacteria, parietal cell count tended to decrease.

\section{References}

1. Arhipova, I., \& Bāliņa, S. (2003). Statistika ekonomikā. Rīga: Datorzinību centrs.

2. Carson, F.L. (1997). Histotechnology: A SelfInstructional Text. Chicago: ASCP Press.

3. Diker, K.S., Haziroglu, R., Akan, M., Celik, S., \& Kabacki, N. (2002). The prevalence, colonization sites and pathological effects of gastric helicobacters in dogs. Turkish Journal of Veterinary and Animal Sciences, 26, 345-351.
4. Eaton, K.A., Dewhirst, F.E., Paster, B.J., Tzellas, N., Coleman, B.E., Paola, J., \& Sherding, R. (1996). Prevalence and varieties of Helicobacter species in dogs from random sources and pet dogs: animal and public health implications. Journal of Clinical Microbiology, 34(12):3, 165-245.

5. Flahou, B., Haesebrouck F., Pasmans, F., D'Herde, K., Driessen, A., Van Deun, K., ... Ducatelle, R. (2010). Helicobacter suis causes severe gastric pathology in mouse and Mongolian gerbil models of human gastric disease. PLoS One, 5(11), 1-11.

6. Fukui, H., Franceschi, F., Penland, R.L., Sakai, T., Sepulveda, A.R., Fujimori, T., ... Genta, R.M. (2003). Effects of Helicobacter pylori infection on the link between regenerating gene expression and serum gastrin levels in Mongolian gerbils. Laboratory Investigation, 83(12), 1777-1786.

7. Geyer, C., Colbatzsky, J., Lechner, J., \& Hermanns, W. (1993). Occurrence of spiral shaped bacteria in gastric biopsies of dogs and cats. Veterinary Record, 133, 18-19.

8. Haesebrouck, F., Pasmans, F., Flahou, B., Chiers, K., Baele, M., Meyns, T., ... Ducatelle, R. (2009). Gastric helicobacters in domestic animals and nonhuman primates and their significance for human health. Clinical Microbiology, 22, 202-223.

9. Happonen, I., Linden, J., Saari, S., Karjalainen, M., Hanninen, M.L., Jalava, K., \& Westermarck, E. (1998). Detection and effects of helicobacters in the healthy dogs and dogs with signs of gastritis. Journal of the American Veterinary Medical Association, 213, 1767-1774.

10. Happonen, I., Saari, S., Castren, L., Tyni, O., Hanninen, M.L., \& Westermarck, E. (1996). Comparison of diagnostic methods for detecting gastric Helicobacter-like organisms in dogs and cats. Journal of Comparative Pathology, 115(2), 117-144.

11. Hermanns, W., Kregel, K., Breuer, W., \& Lechner, J. (1995). Helicobacter-like organisms: histopathological examination of gastric biopsies from dogs and cats. Journal of Comparative Pathology, 112, 307-318.

12. Hwang, C.Y., Han, H.R., \& Youn, H.Y. (2002). Prevalence and clinical characterization of gastric Helicobacter species infection of dogs and cats in Korea. Journal of Veterinary Science, 3(2), 123-156. 
13. Joo, M., Kwak, J.E., Chang, S.H., Kim, H., Chi, J.G., Kim, K.A., ... Kim, K.M. (2007). Helicobacter heilmannii-associated gastritis: clinicopathologic findings and comparison with Helicobacter pylori-associated gastritis. Journal of Korean Medical Science, 22, 63-69.

14. Kakehasi, A.M., Mendes, C.M.C., Coelho, L.G.V., Castro, L.P., \& Barbosa, A.J.A. (2007). The presence of Helicobacter pylori in postmenopausal women is not a factor to the decrease of bone mineral density. Archive of Gastroenterology, 44(3), 266-270.

15. Kanou, Y., Fukui, D., Yamamoto, S., Shibahara, T., Ishikawa, Y., \& Kadota, K. (2005). Gastroinvasive Helicobacter infection in ocelot (Leopardus pardalis). Journal of Comparative Pathology, 133, 281-285.

16. Kaori, N., Shinichi, T., \& Masahiko, N. (2004). Helicobacter heilmannii-like organisms invading into parietal cells brought about apoptosis under acid suppressant administration. Progressive Medicine, 24(3), 692-695.

17. Lanzoni, A., Faustinelli, I., Cristofori, P., Luini, M., Simpson, K.W., Scanziani, E., \& Recordati, C. (2011). Localization of Helicobacter spp. in the fundic mucosa of laboratory Beagle dogs: an ultrastructural study. Veterinary Research, 42(1), 1-9.

18. Paura,L., \& Arhipova, I. (2002). Neparametriskās metodes. SPSS datorprogramma. Jelgava: LKC.

19. Robic, M., Artukovic, A., Beck, A., Gudan, A., Svetina, A., \& Grabarecic, Z. (2007). Histopathological changes in stomach of dogs with naturally acquired Helicobacter infection. Veterinarski Arhiv, 77(2), 103-111.

20. Shao, J., Sartor, R.B., Dial, E., Lichtenberger, L.M., Schepp, W., Alpers, D.H.
(2000). Expression of intrinsic factor in rat and murine gastric mucosal cell lineages is modified by inflammation. American Journal of Pathology, 157(4), 1197-1205.

21. Simpson, K.W., Strauss-Ayali, D., Scanziani, E., Straubinger, R.K., McDonough, P.L., Straubinger, A.F., ... Calam, J. (2000). Helicobacter felis infection is associated with lymphoid follicular hyperplasia and mild gastritis but normal gastric secretory function in cats. Infection and Immunity, 68, 779-790.

22. Smolka, A.J., \& Backert, S. (2012). How Helicobacter pylori infection controls gastric acid secretion. Journal of Gastroenterololgy, 47(6), 609-618.

23. Terio, K.A., Munson, L., \& Moore, P.F. (2011). Characterization of the gastric immune response in cheetahs (Acinonyx jubatus) with helicobacter-associated gastritis. Veterinary Pathology, 49(5), 1-10.

24. Vorobjova, T., Hurlimann, S., Zimmermann, A., Uibo, R., \& Halter, F. (2005). Helicobacter pylori gastritis: glandular proliferation and homeostasis differ between gastric antrum and corpus. Acta Medica Lithuanica, 12(3), 18-27.

25. Wang, F., Xia, P., Wu, F., Wang, D., Wang, W., Ward, T., ... Yao, X. (2008). Helicobacter pylori VacA disrupts apical membrane-cytoskeletal interactions in gastric parietal cells. Journal of Biological Chemistry, 283(39), 26714-26725.

26. Yamasaki, K., Suematsu, H., \& Takahasi, T. (1998). Comparison of gastric lesions in dogs and cats with and without gastric spiral organisms. Journal of American Veterinary Medicine Association, 212, 529-533. 